\title{
Cultural and Religious Identity: The Development of Muslim Community at Lembah Baliem "Wamena- Papua"
}

\author{
Helmawati ${ }^{1}$, Rudihartono Ismail ${ }^{2}$ \\ ${ }^{1}$ Universitas Islam Nusantara, Jl. Soekarno Hatta No. 530, Sekejati Kec. \\ Buahbatu, Bandung, Jawa Barat \\ ${ }^{2}$ Universitas Amal Ilmiah YAPIS Wamena, Jl. Yos Sudarso Kotak Pos 148, \\ Kab. Jayawijaya, Papua \\ E-mail: ${ }^{1}$ helmawati.dr@gmail.com, ${ }^{2}$ rudihartonoismail6889@gmail.com
}

\begin{abstract}
Islam is the second largest religion in the world, while in Indonesia Islam is the majority religion adopted by people in Indonesia. However, in some islands such as Papua, Islam is still a minority. This study focused to describe cultural and religious identity especially Muslim community at Lembah Baliem "Wamena-Papua". The data on this field research was collected by observation (participative observation) and interview. For cultural anthropology, research phase in collecting data consisted of observation, recording, verification, and description facts of Muslim Society in Wamena. The focuses of this discussion are the history of entrance of Muslim in Wamena, how the development of the Muslim community, and how identity of religion and culture of Muslim community in Wamena.
\end{abstract}

Keywords: religious, culture, identity, islamic development, Wamena.

\section{A. Introduction}

Islam is the majority religion adopted by people in Indonesia. Based on survey by Global Religius Futures (Kusnandar, 2018), In the world, Indonesia became the first largest Muslim population country (Kusnandar, 2018a). Based on the data, population of Muslims in 2010 reached about 209.12 million people or around $87 \%$ of the total Indonesia's population. And in 2020, 
Indonesia's Muslim population is expected to reach until 229.62 million people. However, on some islands such as Papua especially Wamena, Islam is still a minority religion. At present, the number of Muslim communities in Papua has reached 900 thousand of total population of around 2.4 million or occupying $40 \%$ of the total population of Papua. While $60 \%$ of the population are Christians, Catholics, Hindus. As in Indonesia historically and socially are so plural, relationship among religions become so complex. In the psychology of minority, a group of religious minority has a specific psychology which draws on fears when facing the surrounding majority group (Idi Warsih, Yusron Masduki, Imron, Mirzon Daheri, 2019). So, it is crucial to study within Islamic minority in contemporary Indonesia (Mahfud, 2018: 471-502).

The development of Muslim community in the Baliem Valley or Wamena becomes interesting to disclose when accessing to the location is difficult to be reached by any transportation except airplanes. Most of the highlighted news in the media was about the riots. When the riot happened, government usually controlled or blocked (McQuail, 2011: 247) the access to mass media to reduce the effect of the conflict. Reports about the development of society were rarely in the spotlight. It became an impact on the lack of information about the development of Muslim community in the central mountain region on the island of Papua as well.

Another external challenges for Muslim communities in Wamena beside lack of transportation and media of communication are geographical condition, the fact that some original people of Papua who want their independence, and the presence of Christian missionaries who had already developed their teachings in that island. The Christian as majority population in Wamena contributed to the dominance of the number of churches as their religious and cultural identities. Because of Islam is minority in Wamena, for building a mosque as an identification of places for worship, deliberation, and Muslim education, is not easy. It almost the same with the case of Yasmin Church, when the minority lived with the majority (Mu'ti, 2019: 111-134); (Burhanuddin, Nunu, Ahmad Ali Nurdin, 2019: 189-216).

The challenges of developing a Muslim community mainly came not only from external, but also from internal of Muslim community itself. The complexity of issues such as aqidah (believing system of Tauhid), organizational, socio-political (Minardi, 2018), and economical background became challenges of Muslim existence in Wamena. When pluralism is juxtaposed with 
religion, the adherents of the religion will retain the specific characteristics of their teachings (Thoha, 2005: 14). Anis Malik Thoha then pointed out that the very crucial reality at the moment whether the idea of puralism really able to provide a friendly solution to conflicts between religions.

The Indonesia state guarantees the independence of each inhabitants to embrace religion and worship according to their religion. It emphasizes that everyone has freedom to believe (Pemerintah, 1945). As the principle of religious freedom, "everyone has the freedom, either alone or in community with others, publicly or privately, to manifest his religion or belief in teaching, practice, worship, and obedience" (Tore Lindholm, W. Cole Durham, Jr., 2004: 147-172). Syamsul Arifin, Hasnan Bachtiar, Ahmad Nur Fuad, Tongat Wahyudi assumed a theoretical position about religious minority groups in a country that claimed that government authorities tent to respect the majority and guaranteed public order (Syamsul Arifin, Hasnan Bachtiar, Ahmad Nur Fuad, Tongat, 2019: 295-326), rather than protecting the religious freedom of their citizens (especially minorities) (Tore Lindholm, W. Cole Durham, Jr., 2004).

Through historical, cultural-anthropological, and psychological approach qualitatively revealed how Muslim trans migrants with backgrounds in beliefs, religion, cultures, ethnicities, customs, and different languages, were increasingly among the majority Christian community of Wamena. The data on this field research was collected by observation (participative observation) and interview. For cultural anthropology, research phase in collecting data consisted of observation, recording, verification, and description facts (Koentjaraningrat, 2015) of Muslim Society in Wamena. The focuses of this discussion are the history of entrance of Muslim in Wamena, how the development of the Muslim community, and how identity of religion and culture of Muslim community in Wamena.

\section{B. Result and Discussion}

\section{History of Muslim in Wamena}

Many histories told how Islam came to Indonesia's Islands, as Islam came to Wamena. The theories of Islam came to Indonesia was written by historians. Until now those theories were still being debated. Michael Laffan the world historian, did not know exactly about mechanism of Muslim settle- 
ments, whether they were intermediaries working for Chinese trade or working for the Chola kings in South India (Laffan, 2015). Other theory mentioned about history of maritime trade and seafaring adventurers, it has contributed a small number of immigrants (Husin, 2019: 279). In the history books of spreading of Islam in Indonesia, included in Michael Laffan's book, there was no information yet about the spreading of Islam in Papua (Irian Jaya). Based on the interviews, it was found that Islam had been in Irian Jaya far ahead of other religions. The spreading of Islam mostly carried out by sea travel when trading, then some were settled (Management YAPIS, 2018), and the others because of a state duty.

Information was obtained based on interviews with some figures in Jayapura and histories. The influence of Islam came from Sultan of Ternate/Tidore in North Maluku saw in the Fak-Fak Regencies, Sorong and Merauke Regencies (J.F., 2006: 75). The name of Raja Ampat in Sorong related with the Islamic empire mentioned above. Meanwhile in Fak-Fak was known RajaFatagar, Patipi, Rumbati, Ati-ati, Namatote in Kaimana, Sekar in Coke and many more. The kings were the representative of the Sultan's power and managed their people in customerelly. Meanwhile on the North Coast, around Jayapura, especially in Abepura, the Muslims came from North Sulawasi (Buton), as well as in Bonggo, Sarmi, could be seen until now those who a few centuries ago entered Irian Jaya.

In Bonggo, there was a Islamic village. And now is only bush. Their situation at the Dutch colonial rule was clearly very depressed, both socioeconomic and religious life, in the education as well. In that time, even the Fak-Fak population almost all were Muslim, but there was no Muslim's madrasa or school. There were only schools under other religious communities, whether Catholic or Protestant.

In other fact, Irian was known as "Digul or Tanah Merah (Red Land). This land was a place of partisans and pioneers of the nation's independence who were exiled and most of them were Islamic scholars or theologian (ulama). In Kaimana, there was Muslim local organization named Persatuan Oemoem Islam Kaimana, so was in Sorong. Basically, the Muslim leaders besides fighting for the unification of Irian into the territory of the Republic of Indonesia also carrying out religious teachings and recitation.

Furthermore, the development of Islam in Papua, especially in Wamena, as stated by Darisman (Darisman, n.d.), that in 1960, about 6 tribal chiefs 
from the Baliem Valley or Wamena made a formal appearance to Soekarno as President in Jakarta to sent skilled workers to educate people in Wamena to plant well and to train in carpentry to build healthy houses. After passing the test, there were 38 people who were all Muslim sent to Wamena. The "Panggilan Bhakti" Mosque had been prepared for that pioneers. From that mosque then began the process of Islamic Education in Wamena which later became pioneer in the establishment of the Islamic Education Foundation in "Tanah Papua" called YAPIS (Darisman, 2006).

General Chairperson and first secretary of YAPIS in central Jayapura as informants told that YAPIS was established based on the urgency of Muslims in Papua at that time. The employees who were sent to Papua (Irian Jaya) were Muslim worked as civil and private employees. They confused when they were going to send their children to school since educational institutions that developed at that time were educational institutions established by the Christian Foundation. Because of the reason, the need of Muslim school became necessity to be established.

After Irian Jaya was released, the first Muslims who tried to realize Islamic education were in Kaimana by trying to build a building and for the first time also the government of the Republic of Indonesia provided assistance to Muslims in Irian Jaya. It happened in early 1963, now the Madrasa became the first madrasa in Kaimana of YAPIS besides the one in Merauke (Helmawati, 2018: 72).

\section{The Development of the Muslim Community in Wamena}

Islam in Wamena began with the assignment of government employees. Their skills were used to educate people in Wamena to plant well and to train in carpentry to build healthy houses. State officials who were sent to Wamena brought their families and settled there. The "Pangilan Bhakti" mosque which was established before the employees arrived was not only a place for worship but also a place for education of the employees' children in Wamena. Furthermore, to fulfil the educational needs of their children, then they established of the Islamic Education Foundation in Tanah Papua (YAPIS) (Darisman, 2006). Education can be as media to spreading Islam teachings, as Fethullah Güllen's missionary schools in Central Asia and their role in the spreading of Turkism and Islam (Balci, 2003: 151-177). 
Transmigration of people from one place to another also became the reason of development of Muslims in Wamena. History of maritime trade and seafaring advent urers, it has contributed a small number of immigrants (Husin, 2019). The government of Indonesia also provided an opportunity to spread the population of the densely populated island to the sparsely populated island (transmigration). The Transmigration Program carried out by the Indonesian government after its independence has been carried out since 1951 through the National Reconstruction Bureau (BRN) program (Suparlan, 1998: 23). The program, which lasted until the end of 1954, channelled ex-combatants who did not find work, mostly rural residents (S., 1986: 20-26).

The dynamics of transmigration since the colonial era until the era of decentralization (regional autonomy) provides many outputs, outcomes, and benefits, including its impact (Prihatin, 2013). In the context of transmigration as a program to improve regional development equality and strengthen national unity, transmigration settlements were expected to be able to develop well and to be able to have a positive impact on the development of the surrounding area (Junaidi, Ernan Rustiadi, Slamet Sutomo, 2012). The arrival transmigrants provided an additional population in Wamena. Settlers who had already established their life, invited people in their home regions to join them in clearing land in Wamena. Their economy was growing through trading.

The policy of the existence of transmigration had increased the number of Muslims in Wamena. As it claimed by Leonard (2003) in Lori Peek (Peek, 2005), stated that Islam was a fast-developing religion. Islam was a fast-developing religion in the world. According to Leonard (2003), Islam is the fastest growing religion in the United States and is poised to surpass Judaism and become second only to Christianity in the number of adherents.

Creative and innovative programs, especially regarding socialization and assimilation (Mahfud, 2018: 471-502) job opportunities for the unemployed were the cause of the increasing people came to Wamena. Some migrants worked as construction, traders, employees and others. The more economy was getting progress in Wamena, the more job opportunities were opened to the community, both for educated and skilled workers and not.

Scholars from various regions are also offered to join in YAPIS as educational institution established in Wamena. Because the founders of YAPIS in "Tanah Papua" were civil servants, they needed human resources who carried out their educational institution. In the migrants' hands (through 
Helmawati, Rudihartono Ismail: Cultural and Religious Identity: The Development of Muslim Community at Lembah Baliem "Wamena-Papua" (page 211-228)

YAPIS) who most of them are Muslims, the number of educational institutions from the preschool level to universities were growing rapidly. And in Wamena, at the beginning of 2020, Institution of Social and Political Sciences (STISIP Amal Ilmiah Yapis Wamena) has transformed into University (Universitas Amal Ilmiah YAPIS Wamena) (jubi, 2020); (suarapapua, 2020); (kabarpapua, 2020), (republika, 2020); (regional.kompas, 2020).

The movement of tabligh congregation spread Islam throughout Indonesia strengthened the existence and the increasing number of Muslims. Many of them later settled and married in Wamena. From observation and interview one of teacher in Walesi, the location is the third ring of Jayawijaya mountain, told that the teacher was one student who just graduated from pesantren were sent by their Kyai to spread Islamic teachings as a form of service for one to two years. Some students who felt at home, finally settled in Wamena.

The interaction of migrants with indigenous people had been a good influence on socio-economic, cultural, and educational developments. Transmigration programs could make trans migrants and indigenous people improving their standard of living (Suparlan, 1998: 25). As in many researchers found that migrants improve a society by bringing new ideas and enriching the culture. This means that migrants are part of a nation-building effort (Spoonley, 2014: 6) and provides benefits. In fact, the interest of indigenous people towards Islamic teachings could not be denied (papualives, n.d.). Eventually many indigenous people embraced Islam, included the Dani tribe (Helmawati, 2018a: 88). Tribal chief of Dani named Tauluk Asso who lives in Walesi, is a fact of the indigenous people who convert to Islam.

The number of mosques increased proportionally to the increase in the Muslim population in Wamena. Because most of the religion in Papua are Christians, it is natural to find many churches in Papua. Rudihartono Ismail (Ismail, 2012: 38), informed that worship facilities spread across Jayawijaya Regency in 2010 were 303 Protestant Church, 133 Catholic Churches, 23 Mosque, and 1 Temple. At present in Wamena, the largest mosque has been built. It is called Masjid Agung Baiturahman Wamena, which is not far from Taman Salib "Wio Silimo".

\section{Religion and Culture of Muslim Identity in Wamena}

Religion exists as a set of diverse yet commonly held belief systems from which individuals may gain benefits (e.g., health and well-being; Haslam et 
al., 2009). Those who are highly identified with their religious group not only share common beliefs but also, by definition, perceive their group membership as central to their self-concept, thereby gaining a sense of personal or collective self-esteem from that membership (Luhtanen \& Crocker, 1992) and a strong bond with other group members (Cameron, 2004) (Ysseldyk, Renate, Kimberly Matheson, 2010). Islam is the religion of over one billion people in the world today, and its followers are called Muslims. The majority of Muslims live in the large area stretching from Morocco in the west to Bangladesh in the east, in the steppes of central Asia to the north, and the island world of Indonesia to the south (Küng, 1988, 197-198). All Muslims are linked by a simple confession of faith - there is no God but Allah, and Muhammad is his prophet - together with five basic lifelong obligations and absolute submission to the will of Allah (K $\square$ ylü, n.d.).

Religious identity of Muslim shows in their believes and habits (cultures). Muslims believe in one God (Esa). The Qur'an and Hadith, Ijma and Qiyas are guidance for Muslims life. The mosque is a place of Muslims to carry out worship. Believe that the last Prophet is Muhammad saw. There are 4 Mazhab followed by Indonesian, namely: Hanafi, Shafi'i, Maliki, and Hanbali. Syafi'i's mazhab is the most followed by Muslims in Indonesia (Baharun, 2012). There are five pillars of Islam as basic rules that all Muslims must follow, i.e. Shahadah (declaration of faith), salat, fasting on ramadhan, zakat, and hajj.

Habitual action from implementing religious teaching will become culture for Muslims themselves. Many rituals individually or socially from religious habit shows Muslims cultures. Islamic values teach Muslims to do good deed and stay away from atrocities; carry out what Allah commands and stay away from everything that God forbids (amar ma'ruf, nahi munkar). The elements of religious identity are the presence of priests, spiritual values (magic), religious ethics (norms), religious cultural symbols (including rituals). When social differences increase, the habit of helping one another's neighbors at work and meeting immediate needs begins to be transformed into a habit of mutual help among diverse social classes. This process was reflected in religious ethics from the start (Weber, 2012: 462).

In doing worship, Islamic teachings never shows social stat us. Everyone is same in front of God, their faith which make the difference. That is why, the background of migrants' Muslim organizations were not an obstacle. 
Helmawati, Rudihartono Ismail: Cultural and Religious Identity: The Development of Muslim Community at Lembah Baliem "Wamena-Papua" (page 211-228)

Muslim leaders in Wamena do not discriminate between Muslims from NU, Muhammadiyah, Persis, and others. This is called accommodation. Accommodation is a social process whereby people try to accept one another, avoiding the sources of conflict to live in peaceful coexistence. It is a conscious adjustment and compromise among conflicting groups so that they can live with one another without overt conflict (Doda, 2005: 166).

In the mosque, worship was carried out by embracing all communities, not only specific Islamic community, such as NU, Muhammadiyah, Shia, or Wahhabi (Mahfud, 2018: 475). According to Halim, this was done in order that the community was accepted by all circles and all Muslims in the country. Tarawih praying, for example, requires between eight and $20 \mathrm{rak}^{\prime} \mathrm{ah}$. The jam'ah (congregation), in this instance, are free to choose. In interaction among Muslims and other members of faiths respect each other to carry out worship according to their respective beliefs. Muslims are obligated to practice their religion properly and correctly according to Al-Qur' an and Sunnah. Then creating a variety of creativity to build civilization. These good habitual actions are called hablum minallah and hablum minan naas.

Differences in beliefs internal Muslims or with other religious do not become cause of breaking its unity. All Muslims with variety of mazhab and organization background belief that the differences are sunatullah and its do not become an obstacle to advancing Muslims in Wamena. By showing an attitude of tolerance (Ranjabar, 2015: 107), all work together, helping for prosperity and the progress on their own fields. The existence of The Great Mosque (Masjid Agung) Baiturahman Wamena where the location is across from "Taman Salib Wio Silimo" is as symbol of respect and tolerance to communities' belief.

Mosque as identity is used to do transcendent worship and humans' relationship. The Great Mosque of Baiturahman Wamena is used to carry out various worships. Beside five time a day of praying in mosque, on Friday the Great Mosque became the center for Friday prayer in congregation. The dawn prayer movement in congregation or called Shalat Subuh Berjamaah has also been held at this mosque. On Monday and Thursday, some Muslims always breakfast together from Shaum in the mosque. Furthermore, other activities besides recitation of Al-Qur'an, also reading activity for Surah Yasin together (Yasinan) on Thursday night. These activities provide an Islamic atmosphere in addition to strengthening friendship between migrant Muslims and become 
the main attraction of Islam itself.

Educational institutions in Islam that contribute to science is a mosque. For Muslims in carrying out their worship activities, they cannot be separated from the mosque. According to George Makdisi (Makdisi, 1998: 21) in The Rise of Collages conveying the sign that the institution that functioned for the initial learning or teaching activities of Islam was a mosque (Triayudha Anna, Rateh Ninik Pramitasary, Hermansyah Akbar Anas, n.d.-a: 142-153).

Beside has function as a place to do the worship and and education, mosque is a place to strengthen friendship (silaturahim) among Muslims, the mosque is also used as a place of deliberation (musyawarah) for Muslims in Wamena. Various problems were deliberated for the welfare and progress together, both social, economic, political, security, and education, for migrant Muslims or for the region and native residents (indigenous people) of Wamena. They help each other and strengthen the family ties under Islamic faith. They unite to build progress and prosperity together.

Meanwhile, to organize activities of Islamic Holidays Celebration is centered on Jayawijaya Baznas Building. Jayawijaya Baznas Building is located on wide location, where the Masjid Agung Bairutahman Wamena is in its area. The capacity of the building can accommodate about 1000 (one thousand) people. For instance, the activities of Isra 'Mi'raj were attended by more than a thousand Muslims. Number of Muslims who were presence accumulated from the seats inside the building were about for 1000 people and added by Muslims who stand outside the building. Based on the information, this number did not show the total number of Muslims in Wamena yet, because many of them were absent because of in duty, and other reasons. Beside from being used to hold Islamic holiday celebrations, this building is also used for other social activities, such as sport and wedding.

Tolerance or mutual respect, critical attitude and problem solving, communicative, and collaborative, become the attitudes (cultures) of Muslims in Wamena. These attitudes show the brotherhood of compatriots and fellow citizens. Although different tribes, languages, and beliefs, all unite for a more advanced civilization. In Wamena, in order to survive, fellow citizens help one another. If some faced problems in their economic life or sick or died, the migrants under the community forum will help each other. This attitude of mutual assistance was very important considering the cost of transportation from inside to outside of Wamena is very expensive. 
Helmawati, Rudihartono Ismail: Cultural and Religious Identity: The Development of Muslim Community at Lembah Baliem "Wamena-Papua" (page 211-228)

The attitude of tolerance of Muslims in Wamena does not leave the beliefs adopted. Acculturation or culture contact is shown both by migrants and indigenous population. Historically, the movement of migration has led to encounters between different groups of people and cultures (Koentjaraningrat, 2015: 202). For example, if there is a party or a big event, the tradition of native residence will hold the Stone Burning or "Bakar Batu". Culture of "Bakar Batu" is the process of cooking at large amounts of food using burning stone as media. The meat that is burned is pork. For Muslims who forbid eating pork, chicken is usually burned instead. Another attitude of mutual respect is when interacting with the indigenous culture of the people of Wamena at the "Baliem Valley Festival", Muslims participating in supporting the activities in cooperative way. Even the tribes of Wamena used Koteka, Muslims appreciate the indigenous culture they believe.

Islam burried the dead body, when local citizen in Baliem Valley or Wamena burnt or in Aikima Village, Kurulu District, Jayawijaya Regency, the dead body was processed into mummy. This tradition or culture is certainly different from the beliefs of Muslims who buried their bodies. Proper communication was done with indigenous people who still hold a culture of customary rights.

The migrant Muslims not only respected and tolerated, but also adjusted to the local culture when the culture was suitable to Islamic values. Religious behavior of Muslims in Wamena adds to the treasury of civilization without leaving the local culture. The tradition of Papuan's food, namely Papeda and tubers became part of the lifestyle of Muslims in Wamena. Foods such as in boxes as a modern lifestyle also were seen when its distributed to all audiences who came during the Isra' Mi'raj. Not only rice and dishes in the box, the contents also added by fruit and even soft drinks. Even though the price of chicken or fish, and other basic foodstuffs in Wamena are very expensive they still show their identity in food lifestyle.

In fashion, Baju Koko, Gamis, and Hijab as identity of Muslim clothes showed in Wamena. The clothes worn by Muslims in Wamena were modern as modern as other regions. A variety of the latest clothing models in Pasar Baru or Tanah Abang Jakarta, also exist in Wamena. Even though the price is certainly very expensive compared to other islands because the place is difficult to reach by land travel, but all the needs are available. In addition to the traditional market, the items needed are also available at Wamena Mall. 
Hijab as Muslimah's cultural identity is emphasized by Lewis in Diana Davis (Davis, 2017). It said that many Muslim women choose to wear the hijab for many different reasons. As this tends to make them more noticeable than women from other cultures, some women from this culture feel especially motivated to fit the hijab in with the rest of their attire. This does not mean they are willing to abandon their distinctive way of dressing, because within that culture, it is an important way of expressing their devotion; they simply want to be able to do both (Lewis, 2010).

Jayawijaya Regency or Wamena has a wide diversity of tribes and languages. There are three major tribes, namely Ngalum, Dani, and Yali. In addition to the three major tribes, there are a number of other tribes including migrant tribes from all over Indonesia. While the number of languages so far have not been determined certainty. In addition there are various social relationships that organize social life. The social relationship is based on kindship (Helmawati, 2018: 89) (silaturahim), this is identity and culure of Islam teaching.

The attitude of transmigrate and local community or tribes did not show hostile but embrace each other as the same country. Understanding and friendly communication showed by Muslims in Wamena. Migrants and native residents (indigenous people); Muslims and Christian live in harmony, hand in hand. Communication was done by formal or gesture and other social activities such as giving food for local communities.

This attitude was also apparent in activities in educational institutions (YAPIS), they worked together in harmony. There are also migrant lecturers who are Christians joined in Muslim educational institutions. All worked hand in hand for the advancement of education in Wamena. And even more amazing is, most students are generally from native (indigenous) children. Therefore, it is not surprising that many of them become officials both in their regions and in national level.

Clean culture is one of Islamic teachings which delivered in YAPIS institutions in Wamena. It is pointed to clean oneself and environment. Beside taking a bath, wudu is one of a way to clean our body. Wudu is done minimum 5 times a day before praying. In Wamena especially in YAPIS institution teachers taught local students to take a bath. And because of this clean culture too, some tribes enter to Islam (ypsa, 2016). 
The collaboration of migrant Muslims could also be seen in Ramadhan days. Like the Ramadhan Ta'jil Market Program which was held in the court near Mall Wamena. Beside this program helped economy in Muslims community also showed religious identity in Ramadhan days (antaranews, 2019).

Muslims in Wamena respect to local arts and cultures. There are arts and cultural tourism such as custome (koteka), mummy, war competitions, pig races, flower festivals, blowing pikon, as well as dances and other traditional activities such as burning rocks (Bakar Batu) which are held every early August. There are also nature tourism such as the eternal snow mountain, Lake Habema at an altitude of 3,450 m, Natural Cave, Salt Lake, winding Valley, colorful flowers and other tourist objects that are generally still natural and beautiful.

To support tourism and at the same time these chances create jobs for women and youth as well, the Jayawijaya Regency Government in collaboration with LIPI and BPPT developed various home industry products that were used as souvenirs for tourists, and household equipment. Home industries developed include pottery or ceramics, rattan weaving, talimulele and pandanus leaves, weaving fleece, sewing, automotive repair shops, various types of chips, fruit syrup such as pineapple, and making sweet potato flour, banana and soybeans flour.

Religious activities as culture identity had an impact on the Muslim brotherhood (ukuwah Islamiyah) and Islamic development in the mountains of Central Papua. The socialization of migrant Muslims with indigenous people opens opportunities for the improvement of culture and civilization in Wamena. Nothing in this world is perfect. The difference is a complement for one to another. The different and unique talents and abilities of each individual become a specialization in fulfilling work in his community. The right understanding of the difference becomes a blessing in society to live together peacefully and harmoniously, this what Islamic teachings say. Sunaryo Kartadinata (Kartadinata, 2015: 33) quoted Fethullah Gulen stated that conflicts in the world occured because of the on going polarization, distrust and hostility between different groups in a society. The solution for that situations was by intensifying communication and mutual understanding between groups. Besides, all leaders must strive for tolerance so that people can accept each other's differences. 


\section{Conclusion}

History of entrance of Muslim in Wamena or known as Lembah Baliem is accordance with existing theories. Muslim came for trade (maritime trade) or working (state duty), and seafaring adventurers. There were also partisans and pioneers of the nation's independence who were exiled and most of them were Islamic scholars or theologian (ulama).

The development of the Muslim community in Wamena began with the assignment of government employees. Government facilitated mosque to the employees who came. State officials who were sent to Wamena brought their families and settled there. The mosque which was established before the employees arrived was not only a place for worship but also a place for education of the employees' children. Furthermore, to fulfil the educational needs of their children, then they established of the Islamic Education Foundation and for that they invited Muslim scholars from other islands to join. Transmigration also became the reason of development of Muslims in this place. The movement of tabligh congregation increased number of Muslims. Many of them later settled and married in Wamena. The interaction of Muslim migrants with indigenous people had made indigenous people embraced Islam.

Religion and culture of Muslims identity in Wamena showed in habitual actions. Muslims believe in one God and believe that the last Prophet is Muhammad saw. The mosque as a place of worship accommodates a variety of Islamic communities regardless of differences in organizational background or status. The Great Mosque of "Baiturahman" Wamena is used as a place of prayer, reading the Qur'an, studying, deliberation, and strengthen silaturahim. Other religion and culture identities of Muslims are celebrating religious holidays, halal food, fashion, funerals, wudu or body cleaning, and arts. Religious and cultural identities in Wamena show that Muslims and their teachings bring peace, tolerance, and moderate. And Islam has never taught division and enmity to its people.

\section{REFERENCES}

Antaranews. (2019). di-jayawijaya-papua-kkss-fasilitasi-tempat-bagi-penjualtakjil. Retrieved from antaranews website: https://www.antaranews. com/berita/864560/di-jayawijaya-papua-kkss-fasilitasi-tempat-bagipenjual-takjil 
Helmawati, Rudihartono Ismail: Cultural and Religious Identity: The Development of Muslim Community at Lembah Baliem "Wamena-Papua" (page 211-228)

Baharun, M. (2012). Islam Idealitas Islam Realitas. Jakarta: Gema Insani.

Balci, B. (2003). Religion, State \& Society. Cartax Publishing, 31(2), 151177.

Burhanuddin, Nunu, Ahmad Ali Nurdin, M. I. H. (2019). Religious Conflict and Regional Autonomy in Church Establishment and Islamic Clothing in West Pasaman and Dharmasraya West Sumatera. Indonesian Journal of Islam and Muslim Societies, 99(2), 189-216. https://doi.org/ 10.18326/ijims.v9i2

Darisman. (n.d.). Kepala Keluarga Pelopor Pembangunan Irian Barat (PPIB).

Darisman. (2006). Islam Masuk Wamena.

Davis, D. (2017). Examining the Potential Relationship between Religious Identity, Ethnic Identity, and Attitudes towards Sexualized Clothing of Women Living in the United States. Psychology of Florida Institute of Technology.

Doda, Z. (2005). Introduction to Sociology, In collaboration with the Ethiopia Public Health Training Initiative. The Carter Center, the Ethiopia Ministry of Health, and the Ethiopia Ministry of Education, 166.

Helmawati, R. I. \&. (2018a). Meningkatkan SDM Berkualitas Melalui Pendidikan "Menyiapkan SDM Papua Yang Berdaya Saing. ”Bandung: Alfabeta.

Helmawati, R. I. \&. (2018b). Pendidikan di Tanah Papua "Peran YAPIS Membangun SDM Terdidik." Bandung: Alfabeta.

Husin, A. (2019). Being Muslim in a Secular World: Indonesian Families in Washington DC Area. Studia Islamika, 26(2), 279. https://doi.org/ 10.15408/sdi.v26i2.8412

Idi Warsih, Yusron Masduki, Imron, Mirzon Daheri, R. M. (2019). Muslim Minority in Yogyakarta: Between Social Relationship And Religious Motivation. Qudus International Journal of Islamic Studies, 7(2), 367398. https://doi.org/10.21043/qijis.v7i2.6873

Ismail, R. (2012). Mengenal Nusantara Jayawijaya. Bekasi: Sari Ilmu Pratama. J.F., O. (2006). Islam dan Kristen di Tanah Papua. Bandung: Jurnal Info Media. 
jubi. (2020). stisip-amal-ilmiah-yapis-wamena-menjadi-universitas. Retrieved from jubi website: https://jubi.co.id/stisip-amal-ilmiah-yapis-wamenamenjadi-universitas/

Junaidi, Ernan Rustiadi, Slamet Sutomo. (2012). Development Of Resettlement Implementation Under Decentralization: A Special Study Transmigration Interaction With The Surrounding, See discussions. Https:/ $/ W_{W w}$.Researchgate.Net/Publication/275715055.

Kabarpapua. (2020). stisip-amal-ilmiah-yapis-wamena-menjadi-universitas. Retrieved from kabarpapua website: https://kabarpapua.co/status-stisipamal-ilmiah-yapis-wamena-naik-jadi-universitas/

Kartadinata, S. (2015). Pendidikan Kedamaian. Bandung: Remaja Rosdakarya.

Koentjaraningrat. (2015a). Pengantar Ilmu Antropologi. Jakarta: Rineka Cipta.

Koentjaraningrat. (2015b). Pengantar Ilmu Antrpologi. Jakarta: Rineka Cipta. $\mathrm{K} \square$ ylü, M. (n.d.). Islam and Peace Education. Retrieved from Ondokuz Mayis University website: https://www.tc.columbia.edu/epe/epe-entries/ KoyluIslam_22feb08.pdf

Kusnandar. (2018a). The World's Largest Muslim Population, Global religius future No Title. Https:/Databoks.Katadata.Co.Id/Datapublish/2019/ 09/25/Indonesia-Negara-Dengan-Penduduk-Muslim-Terbesar-Dunia.

Kusnandar, V. B. (2018b). The World's Largest Muslim Population, Globalreligiusfuture. Retrieved from https://databoks.katadata.co.id/ datapublish/2019/09/25/indonesia-negara-dengan-penduduk-muslimterbesar-dunia

Laffan, M. (2015). Sejarah Islam di Nusantara (M. A. \& A. H. Indi Aunullah \& Rini Nurul Badariah; penyunting, Ed.). Yogyakarta: Bentang.

Mahfud, C. (2018). Chinese Muslim Community Development in Contemporary Indonesia: Experiences of PITI in East Java. Studia Islamika, 25(3), 471-502. https://doi.org/10.15408/sdi.v25i3.6755

Makdisi, G. (1998). The Rise of Collages: Institutions of Learning in Islam and the West. Edinburgh: Edinburgh University Press.

Management YAPIS. (2018). Yayasan Pendidikan Islam di Tanah Papua. Papua. 
Helmawati, Rudihartono Ismail: Cultural and Religious Identity: The Development of Muslim Community at Lembah Baliem "Wamena-Papua" (page 211-228)

McQuail, D. (2011). Teori Komunikasi Massa McQuail. Jakarta: Salemba Humanika.

Minardi, A. (2018). The New Islamic Revivalism In Indonesia Accommodationist and Confrontationist. Journal of Indonesian Islam, 12(2). https://doi.org/10.15642//JIIS.2018.12.2.247-264

Mu'ti, A. (2019). The Limits of Religious Freedom in Indonesia: with Reference to the First Pillar Ketuhanan Yang Maha Esa of Pancasila. Indonesian Journal of Islam and Muslim Societies, 9(1), 111-134. https:/ /doi.org/10.18326/ijims.v9i1. 111-134

papualives. (n.d.). sejarah-islam-suku-dani-lembah-baliem-papua. Retrieved from papualives website: https://www.papualives.com/sejarah-islamsuku-dani-lembah-baliem-papua/

Peek, L. (2005). Becoming Muslim” The Development of a Religious Identity. Sociology of Religion, 215-242. https://doi.org/66:3 215-242.

Pemerintah, D. (1945). UUD Pasal 28E ayat (1), (2); Pasal 29 ayat (2).

Prihatin, R. B. (2013). Revitalisasi Program Transmigrasi. Jurnal MasalahMasalah Sosial, 4(1). https://doi.org/10.22212/aspirasi.v4i1.487

Ranjabar, J. (2015). Perubahan Sosial "Teori-Teori dan Proses Perubahan Sosial serta Teori Pembangunan. Bandung: Alfabeta.

regional.kompas. (2020). stisip-amal-ilmiah-yapis-wamena-menjadiuniversitas. Retrieved from regional.kompas website: https://regional. kompas.com/read/2020/02/24/16560141/status-meningkat-universitasyapis-wamena-jadi-penyangga-pendidikan-di?page $=$ all

republika. (2020). stisip-amal-ilmiah-yapis-wamena-menjadi-universitas.

Retrieved from republika website: https://republika.co.id/berita/ q5ujs5368/stisip-yapis-wamena-berubah-stat us-jadi-universitas

S., P. (1986). Mencari Suatu Sistem untuk Melaksanakan Pemindahan Penduduk Secara Besar-Besaran dalam Transmigrasi di Indonesia 19051985 (Sri Edi Swasono dan Masri Singarimbun, Ed.). Jakarta: UI Press. Spoonley, P. (2014). Superdiversity, Social Cohesion, And Economic Benefits Superdiversity Can Result In Real Economic Benefits-But It Also Raises Concerns About Social Cohesion. IZA World of Labor, 6. https:/ /doi.org/10.15185/izawol.46 
suarapapua. (2020). stisip-amal-ilmiah-yapis-wamena-menjadi-universitas. Retrieved from suarapapua website: https:/suarapapua.com/2020/02/ 25/stisip-yapis-wamena-berubah-status-menjadi-universitas/

Suparlan, P. (1998). Model Sosial Budaya bagi Penyelenggaraan Transmigrasi di Irian Jaya. Antropologi Indonesia, 23.

Syamsul Arifin, Hasnan Bachtiar, Ahmad Nur Fuad, Tongat, W. (2019).

Minority Muslims and freedom of religion: learning from Australian Muslims' experiences. Indonesian Journal of Islam and Muslim Societies, 9(2), 295-326. https://doi.org/10.18326/ijims.v9i2.295-326 Thoha, A. M. (2005). Tren Pluralisme Agama: Tinjauan Kritis. Jakarta: Perspektif.

Tore Lindholm, W. Cole Durham, Jr., and B. G. T.-L. (2004). Facilitating Freedom of Religion or Belief: A Deskbook. Leiden: Koninklijke Brill NV.

Triayudha Anna, Rateh Ninik Pramitasary, Hermansyah Akbar Anas, C. M.

(n.d.). Relations Between Mosque and Social History of Islamic Education. Hunafa: Studia Islamika, 16.

Weber, M. (2012). Sosiologi Agama. Yogyakarta: IRCiSoD.

ypsa. (2016). 3-712-orang-papua-masuk-islam-karena-sabun. Retrieved from ypsa website: https://ypsa.id/2016/07/14/3-712-orang-papua-masukislam-karena-sabun/

Ysseldyk, Renate, Kimberly Matheson, and H. A. (2010). Religiosity as Identity: Toward an Understanding of Religion from a Social Identity Perspective. Personality and Social Psychology Review. https://doi.org/ $10.1177 / 1088868309349693$ 